\title{
Preface: Provoking Ten Burros and a Genius
}

For the first time in the history of humanity, the earth is truly round.

Marc Augé

In May I 994 I returned to Colonia Santo Domingo, in Mexico City, and quickly found myself part of a raucous street scene. Loud and disorderly streets are nothing new for residents of the neighborhood; indeed, public debates have been common here ever since thousands of $p a$ racaidista (parachutist) land squatters first invaded these volcanic rocks on the south side of the Mexican capital in September I97I. Still, this time there was something new to the excitement: rather than voicing concerns relating to the construction and protection of their particular colonia, residents were expressing anxiety about Mexico's political outlook in general and how elections might fit into this future. And they were arguing about these issues as if their words, actions, and opinions actually might make a difference in national political outcomes.

This kind of engagement with official politics and this kind of enthusiasm for electoral politics, albeit a wary enthusiasm, is not normal in the colonias populares of Mexico City.

I had been gone from Mexico City for several months, and now Gabriel, Marcos, Felipe, and Toño were bringing me up to date in their running argument with one another. As we shared various caguamas of Corona beer, Toño was once again expressing his staunch support for the government PRI party. "They're the only ones with the infraestructura to run the country. Things would quickly deteriorate, everything would be un desmadre [a total mess] if another party won," he chided the others. ${ }^{1}$ Marcos, although an active member of a janitors' union and a sup- 


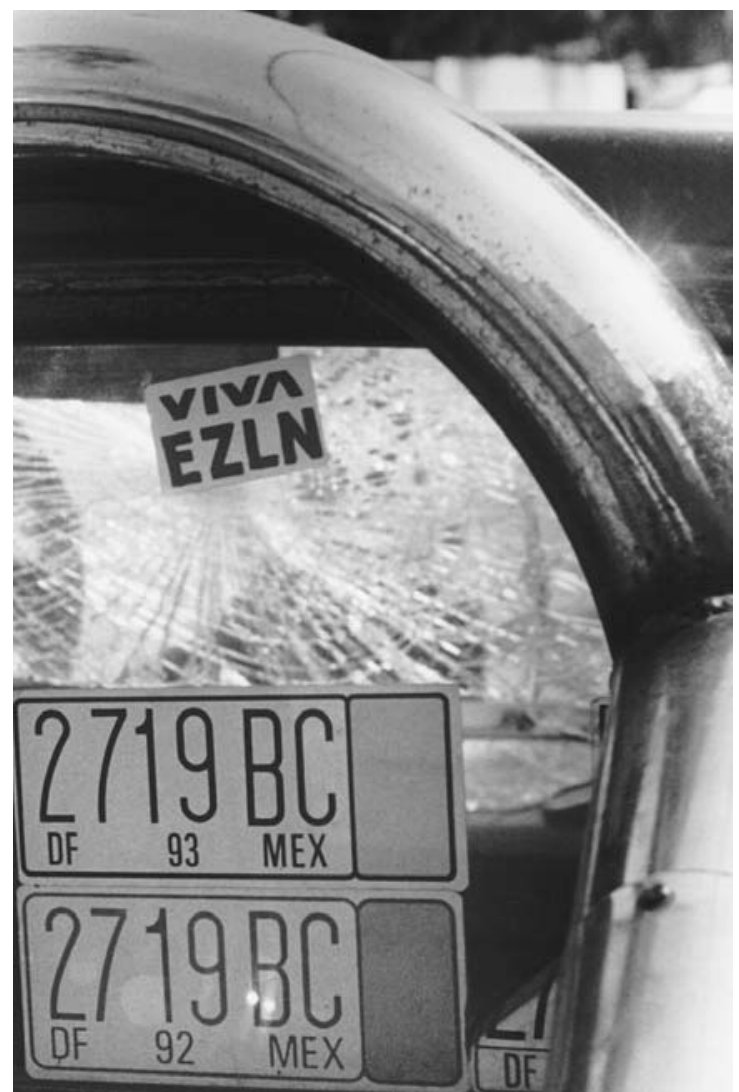

Figure I. After the January I994 uprising in Chiapas, Gabriel liked to put EZLN (Zapatista) stickers on cars he was repairing.

porter of the PRD center-left opposition party, was explaining to Toño that he too had problems with the PRD presidential candidate Cuauhtémoc Cárdenas. This was why, Marcos declared, he was a PRDista sin Cárdenas, a supporter of the PRD but without Cárdenas.

Both Toño and Marcos then began chastising Gabriel, a celebrated mechanic on Huehuetzin Street in Colonia Santo Domingo, for his notorious abstencionista politics - Gabi frequently berated customers and passersby for getting too agitated about elections. After the January I, I994, Zapatista uprising, and for the remainder of I994, Gabi would plaster EZLN (Zapatista National Liberation Army) stickers on many of the cars and jitneys he repaired, and would proselytize from his taller 
(workshop) on the sidewalk about the virtues of effecting political change from outside the electoral party system.

As the lone ecologista in the group, Felipe limited his discussion to periodic reminders that his party was the only one with representatives that anyone on Huehuetzin Street had actually met.

Given the serious nature of the debate and the disagreements, there was an exhilarating sense that the political conflicts among these men concerned important issues and that opposing sides and positions had real consequences for the political fortunes of millions of other Mexicans.

For men and women in Colonia Santo Domingo, I 994 was an eventful year. As did their compatriots throughout the Republic, they witnessed and disputed the Zapatistas' uprising in January, the assassination of PRI presidential candidate Luis Donaldo Colosio in March, the presidential election in August, and a second major political assassination of José Francisco "Pepe" Ruiz Massieu in September. In addition, at the end of that year they suffered yet another major peso devaluation. All these events presented challenges to the political agnosticism of chilango abstencionistas and the defeño disaffected. For a while, for a few months, popular political culture was not the same in Mexico City.

\section{DEMOCRACY AND ITS MALCONTENTS}

In the United States I have never participated in a street debate among old friends such as the one I witnessed in Santo Domingo in May I994. This is not a minor issue. My own curiosity about a periodic passion for politics in many parts of Mexico in the I 990 os was sparked by the knowledge that this kind of interest had been largely lacking elsewhere in North America for several decades. In contemporary Mexico, however, I noted that popular politics involves a tumultuous history of new social movements and electoral politics, political activism and passivity, and, at least among many of my friends and neighbors in one neighborhood of Mexico City in the I990s, a profound and personal engagement with concepts like democracy, agency, and resistance in the subjective lives of men and women.

How can we explain the periodic passion for politics among workingclass people in Mexico City? And why did this fervor often die out as suddenly as it flared up?

In 2000, in Mexico as elsewhere across the globe, many people say that they believe in democracy, that they support democratic efforts and politics, and that to say and do otherwise would be, well, simply 
undemocratic. So if nearly everyone is enthusiastic about democracy, it seems good and appropriate to ask what everyone means by that term. The elusiveness of the term democracy is symptomatic both of the range of aspirations wrapped within its multiple meanings and, ultimately, of its imprecision. For these reasons, in these pages I will not be able to offer a sound-bite definition of democracy; rather, I will seek to show how democracy's very multivalence is a key reason for the zeal with which so many people have employed the term to dramatically different ends in recent world history. Passionate partisanship can disguise a multitude of semantic sins. ${ }^{2}$

Until quite recently, around 1988 to be precise, people from all walks of life in Mexico casually made fun of official politics in their country. There were jokes about the sexenio (the six-year presidential period) and how it resembled a rotating dictatorship; about the use of the dedazo (finger-tap) and destape (unveiling) to choose each presidential successor ${ }^{3}$; about urnas embarazadas (pregnant ballot boxes); about the old-guard political dinosaurios and the young-Turk tecnócratas; about llevando a acarreados, rented-and-transported crowds being trucked to campaign rallies; and about the ridiculously lopsided coverage of electoral politics by government-owned and -affiliated television stations. ${ }^{4}$

The presidential election of 2000 , in which the government-PRI party (Partido Revolucionario Institucional) that had ruled Mexico virtually unopposed for decades went down in defeat, was internationally hailed as a historic watershed for democratization in poor nations everywhere. "A peaceful transition to multiparty democracy," the analysts applauded. In the wake of this transition, it would be a shame not to take advantage of the opportunity to learn from women and men of the capital city about democracy, resistance, and agency; to consider their experiences and hopes for building democratic communities; and to examine what common citizens in Mexico City think about exercising political sovereignty over their own lives.

In the I980s and I990s many leftist observers of Mexico came to place great hope in organized social movements as holding greater promise for democratization than political parties. These expectations were linked to romantic notions of popular resistance, as many searched for social forces to replace the class-struggle framework of orthodox Marxism. Political cultures and the cultures of politics (see Alvarez, Dagnino, and Escobar 1998) became key concepts for the study of politics in Latin America at the end of the twentieth century. The meanings and significance of public and private distinctions in political life, writ large 
and small, became vital to an understanding of the particular regional dilemmas that faced many Latin American societies seeking to make the transition from military dictatorships to more participatory forms of government. Although this specific situation did not apply literally to Mexico, many of the issues explored there during this period were relevant for emerging cultural politics in countries like Argentina, Chile, Ecuador, Brazil, and Guatemala. Similarly, grappling with the relationship between democracy, poverty, and inequality was of paramount importance in grounding broader discussions of the relationship between economic growth and development, on the one hand, and redistribution of resources - "poverty alleviation," in the words of the World Bankon the other.

Throughout Latin America in the early 2000s, commentators used the term redemocratization to describe the political goals sought and the transformations underway in the region. Yet, once again, the ambiguity of the term democracy became readily apparent upon a more than cursory examination, because to talk of "redemocratization" begged the question: When was Latin America ever democratic? What parts of the region had ever enjoyed this democracy that was so cherished in these societies? What did this democracy look like and feel like, or was this preexisting democracy so indeterminate that this entire line of questioning seemed unfair? As Gills, Rocamora, and Wilson $($ I993, 3) wrote in the introduction to their volume on "low intensity democracy," "Whereas some regard formal democracy as sufficient in itself, if the content of this new democracy is critically examined it may be found to be seriously flawed on many counts."

Given the regularity with which the slogans of democracy and resistance were summoned, one would have expected more critical discussion and less ingenuous invocation of the terms. It was not hard to trace the trajectory of similar academic debate on other intricate conceptual and practical questions - for example, on "the indigenous problem" in Mexico. Since the second decade of the twentieth century, in alternating waves of assimilationism and demands for cultural autonomy, scholars, policy makers, and leaders of indigenous groups themselves have tried to find ways to do more than simply make the indigenous peoples of Mexico-numbering greater than ten million in the year 2000, some Io percent of the population-emblems of chronic discrimination in the country. There needed to be similar debate about the conceptual and practical meanings of democracy and resistance.

For many observers of Mexico, a central concern in the past two 
decades has been to account for the emergence of popular social movements as expressions of "the central theme of poverty" (see Nivón I998, 33). Yet, by themselves, these have not been sufficient to effect fundamental, lasting political change. Judith Adler Hellman has been exceptionally astute with respect to this last point, as when she noted, "It could be argued that it is not the role of a mass popular movement to formulate and promote an alternative vision of society- that this is the role of a political party" (I994a, I38; see also Hellman I992). And it is precisely here that we can see certain problems inherent in earlier utopian visions of social movements as providing a panacea to deepseated political inequalities in Mexico and elsewhere. Alternatives to both party politics as usual and stock resistance models need to be developed to more fully explore popular politics in contemporary Mexico.

Perplexingly enough, after decades of full-throttled participation by left intellectuals and activists in deliberations on questions of Mexican national identity, and clashes around the relationship of class to such nationalist concerns, in the past twenty years activists have largely confined themselves to organizing and leading social movements devoted far more to the issues of day-to-day survival than to questions of national sovereignty. Meanwhile, the intellectuals have delved ever deeper into questions of globalization, identity, and ethnohistory, seeking to expand the horizons of space and time, and in the process often abandoning these very issues of contemporary politics and power in a regrettably similar fashion.

\section{U.S. EMPIRE: POINTS OF REFERENCE AND DEFERENCE}

By the year 2000 opposition candidates in Mexico had been elected President of the Republic and mayor of the capital city, and therefore, one might assume, they could serve as political examples of democracy internal to Mexico. Nevertheless, comparisons with the United States continued to be a point of democratic reference in Mexico, especially with respect to various civil rights such as freedom of the press and freedom of assembly, and to a two-party system versus Mexico's single government-party system. Still, it is unclear whether it was actual political freedoms in the United States or, on the contrary, its superpower status that made claims to democratic standard-bearer status valid in the eyes of many people in Mexico.

One reason for questioning the aptness of comparisons between Mexico and the United States is the superficial quality of invidious 
analysis of the content of democracy in each country. Another reason is surely that, with Mexico and the United States, we are not discussing two hermetically sealed nation-states but rather two countries sharing a long border and a history of utterly unequal relations. And, as Steve Stern (I998 a, 5I) noted in an essay on the paradoxes of foreign presence in Latin America: "Perhaps we must begin all over again to conceptualize a foreign presence that is integral yet not totalizing in its power to mold, or a foreign-local relationship that constantly draws cultural boundaries of 'we' and 'they' yet fails to preclude dynamics that confound division into 'we' and 'they.'" Although some commentators seem even more tempted following the fall of the Berlin Wall in I989 and the ensuing collapse of the Soviet Union, comparing democracy in the two countries must be done with great care.

Although many friends and colleagues in Mexico find comparisons to the United States odious on general principle, others there use the United States as a model of where Mexico should be headed. Thus, more than a few might wish to admit, the juxtapositions between these two countries divided by a two-thousand-mile border are, to one extent or another, the transnational currency in which we are dealing in the twenty-first century. ${ }^{5}$ More importantly for readers of this book, perhaps, because people in the United States are unaccustomed to learning from the lives and experiences of people in other countries, especially regarding democracy, I would emphasize early on how much we have to learn from political events and ideas in Mexico. It is hardly a simple matter of what we in the United States have to teach the rest of the world. ${ }^{6}$

Regardless of comparisons, though, a persistent issue for many in Colonia Santo Domingo, and for intellectual and political leaders in the Mexican capital as well, concerns the ability of any society to develop democratically when severe political, economic, and cultural inequalities are obvious to all. ${ }^{7}$ If the wealthiest 20 percent of the population made off with 50 percent of Mexico's income in the early I990s, and the lowest 20 percent earned only 5 percent of the GNP (see Oppenheimer I 998, 89), by what standards are we to judge such mundane matters as popular participation in political decision making? Is survival to be the only salient issue for the poor, whereas the elites will have the liberty to dally in issues of statecraft?

Perhaps we should be less exclusively interested in gauging how well Mexicans are achieving so-called democratic values and institutions, how they are coping with the issue of campaign-financing limits, or how effectively election monitors that have been chosen from the in- 
ternational community have worked. There is a place and a real need for such research and speculation, and certainly the forms and substance of compliant defiance in contemporary Mexico can be comprehensively charted only by comparing studies utilizing mixed methodologies. But we need to ask other questions about political defiance and compliance as well.

\section{AGENCY AND VICTIMIZATION}

To what extent do people exaggerate their political influence? Whom should we regard as the ultimate arbiters of such influence-social actors or outside political observers? Without delving into the peculiar realm of the political unconscious, what people in my neighborhood of Mexico City claim to know and not know is often directly linked by them to their activity or inactivity. Further, these same friends in Santo Domingo often directly associate knowledge and actions, on the one hand, and culpability, on the other.

One way to approach the matter of the compliant defiance of working-class women and men in Mexico City is to (re)examine the concept of agency. The term agency, as it has been used in the past two decades or so, has been popular because it has the great merit of challenging determinist thinking in the social sciences. With agency, the dispossessed are seen to have a fuller voice in deciding their own fates and even have a hand in human tragedies, an example being the voluntarist fervor with which German citizens slaughtered Jews in Nazi Germany. ${ }^{8}$ More often than not, however, "agency" has referred rather exclusively to politically progressive efforts of the poor and dispossessed only when they are able to break free of structural and systemic constraints. How one understands failures or situations when the poor and dispossessed dare not even attempt to break out are subjects that many of us have been reluctant to address.

Michael Herzfeld (I997) closely examines questions of agency in his development of the theory of "cultural intimacy." In discussing intracultural diversity and people who are more and less gifted practitioners in the arts of politics, for example, he writes that "skilled actors use the appearance of rigidity to get what they want. Unskilled (or simply unsuccessful) actors blame the system; this is the worldview whereby they also blame the state and so confirm its power" (Herzfeld I997, 20). Skilled actors are not only compared to their unskilled (or unsuccessful) 
counterparts, but are also utilized to adjudicate the anthropological orthodoxy wherein "social actors seemed to be locked into an ideational predestination, the possibility of independent agency all but precluded" (Herzfeld I997, 29).

This propensity to romance the politically successful actors among the dispossessed, as evidenced in many a barren homage to resistance theory (see chapter 6), has unfortunately resulted in less than adequate analyses with respect to the politically weak-those who are not successful, not interested, or not aware. Even to mention the possibility that poor people may not be "aware," of course, conjures up charges of false consciousness and other censured concepts today. Yet, paradoxically, political passivity, and not simply agency, remains uncharted territory. In her study of transvestites, queens, and machos in Mexico City, Annick Prieur (I998, I 29) makes a similar point. Although her informants are the victims of symbolic (and not so symbolic) violence, they are also actors who choose certain elements of their lives. They are not simply the passive subjects of history.

Most men and women in Colonia Santo Domingo are in the periphery of the mainstream politics of electoral parties, and are also marginal actors in organized social movements, either barrio-based or citywide. The study of popular political interests and activities is certainly more easily accomplished by focusing on organized, public manifestations of incumbent and oppositional institutions, movements, and leaders. But by concentrating as much on abstentionism as on participation, as much on individual political outrage and individual displays of nationalism as on organized forms of protest and rebellion, additional facets of the picture come into focus. It is not that politics and power are ultimately more capillary (à la Foucault) than collective. Rather, it is that there is much to be learned from a stratum of the population that is not made up primarily of political activists, nor truly representative of the inertia and disinterest often considered typical of the impoverished masses.

Another topic related to democratization that has attracted widespread attention in diverse locales is the question of how to conceptualize citizenship as both a general category and with specific reference to marginalized and oppressed groups. In the United States, for example, scholars pose questions about the issue of pluralism. Should citizenship be considered an ideal of inclusion rather than exclusion, and is this a very realistic goal (see, e.g., Ong 1996; Rosaldo I997). In other words, 
to what extent can the values and demands of "full citizenship" be understood as a claim for recognition of multiple forms of civil participation from a diverse array of cultural groups within the larger society? Or, is the concept of equal citizenship really an illusion whose realization is utopian and unrealistic precisely because the larger society is, at its base, founded on and maintained by inequalities that are inherent in its very constitution?

That the right of the socially dispossessed to vote, along with other civil rights, has been a long sought and hard-won accomplishment in Mexico as elsewhere is beyond question. The fact of achieving suffrage and other civil rights, however, is not the same as recognizing how and when to use them effectively to change the world. Wendy Brown has written provocatively about "the emancipatory force of rights" (which would certainly include the right to participate in free elections):

While rights may operate as an indisputable force of emancipation at one moment in history - the American Civil Rights movement, or the struggle for rights by subjects of colonial domination such as black South Africans or Palestinians - they may become at another time a regulatory discourse, a means of obstructing or co-opting more radical political demands, or simply the most hollow of empty promises. ... The point is that rights converge with powers of social stratification and lines of social demarcation in ways that extend as often as attenuate these powers and lines. (Brown I995, 98)

Commenting on this passage, John Gledhill argues for the inclusion of capitalist social relations in any discussion of rights, not because class determines all other modes of domination, but "because it remains a constitutive part of the positioning of social subjects in the arena of struggles over rights" ( 1997,72$)$. In chapter 8, I examine more closely the relationship between the right to vote and gender identities and relations. Among other things, recent work in gender studies in Latin America that has focused on questions of public and private spaces of power has substantially refined our overall understanding of civic rights, modes, and methods of political change at societal and more familiar levels.

Journalists and academics are constantly inventing terms to describe democracy's blemishes and blemished democracies: "rogue democracies," "shallow democracies," and "imperfect democracies" are a few of recent coinage (see Crossette 2000; Rosenberg 2000). The election of Hugo Chávez as Venezuela's president and the reelection of Alberto Fujimori in Peru in 2000 are widely deemed as exemplary of "shortcom- 
ings" in the realization of democratic ideals in Latin America; they are less often discussed in the press or in scholarly forums as illustrative of politics that really had very little to do with democracy in any meaningful sense.

The romance of democracy exists, to be sure, in the possibility of popular participation in politics, and, more irreverently, in the wooing of the populace to believe in utopian promises when their only political future is more of the same. The right to decide upon channels for political participation is on the agenda in Mexico, and the balance between compliance and defiance is, as always, at the center of the debate over the meanings and activities to be associated with citizenship. Yet, what do women and men in Santo Domingo who wish to participate as active citizens in a democratic Mexico actually do when they roll out of bed in the morning? Are their actual options limited to saying to themselves, "Well, only six more years until I can vote again in the presidential election"?

\section{RESISTANCE AND THE PEOPLE}

"A lot of people talk these days about democracy as the goal of all kinds of social struggle," I commented one day in I 997 to Gabriel, my mechanic friend.

"But ask those wise guys if they go to the marches, if they go to the meetings. 'Do you go out and raise hell?' Everyone talks about democracy ..." Gabi complained.

"The Zapatistas, too?" I asked him.

"The Zapatistas practice democracy more because the groups who are prepared are the ones who are marginalized. Why? Because they are the groups who actually can see to it that democracy functions. But that's when people get together and analyze things so democracy doesn't become, as I was saying, ten burros and a genius."

Which, of course, raised for me the obvious question: "And who's to say who are the burros and who are the geniuses?"

"The burros are the ones who talk about democracy and don't practice it," Gabriel responded, just barely managing to keep a straight face.

"Are you a genius or a burro?" I needled him.

"Burro," he replied, laughing. Then, recovering his composure, he added in a half-serious, half-playful tone: "But I'm not a mountain burro, because even burros have hierarchies. There are burros who are more burros than I am, and there are burros less burros than I am. What 
I do think is that there's a lack of educacion and that the level of $e d u$ cación in our country is very low." 9

"But even in countries where the level of formal education is very high there are assholes all over," I commented.

To which Gabi retorted, "And in the end, who's to blame?"

"I don't know," I lied, because I knew where this line of argument was leading. "Tell me," I requested, so I would not have to put words into his mouth.

"The people," Gabriel told me, just as he had on so many other occasions in the years we had been talking about politics and change in Mexico. "The people" bore some responsibility for their own misery, because only the people could, if they became "educated" in the broadest sense of being conscious of their situation, do something to rectify their lives.

And so, before proceeding further, this issue of "the people," sometimes also referred to as "the popular classes," must be briefly addressed. It is as unsettled a subject as any in the anthropology of Mexico today. Earlier taken-for-granted agreements about what constitutes a class are presently undergoing rigorous scrutiny. Skepticism abounds among many anthropologists in Mexico regarding the very utility of "class" as an analytic category (see, e.g., Nieto I998). As one way of conceding the blurry boundaries of the social group that has been variously called the working class, the proletariat, the poor, the dispossessed, and the underdogs, while at the same time acknowledging the obvious fact that disparities of wealth are horrendously glaring and significant in all aspects of social life in Mexico, newer terms like clases populares have come into vogue since the r980s.

Prominent among anthropologists in Mexico who have utilized the term popular classes in their writings have been Néstor García Canclini and Guillermo Bonfil Batalla. This has allowed them to avoid the use of Marxist terminology now regarded by many as hackneyed, while at the same time giving a populist slant to their perspectives and approaches to formulating innovative cultural theory in general. ${ }^{10}$ García Canclini's students and colleagues at the Universidad Autónoma MetropolitanaIztapalapa have produced several pioneering studies on clases populares and urban space (see, among others, Nieto I998; Nivón 1998; and Safa I99I).

Eduardo Nivón (I998), for instance, has written provocatively about "the substitution of 'the popular' for 'the public'" in his study of the impact of the media, the Church, and dominant classes on mass culture in 
recent years. Building upon themes raised by Carlos Monsiváis in various publications, Nivón notes that, especially after I968, the question of how to incorporate poverty and daily life into accounts of culture and society have been at the center of studies on popular culture and Mexican national culture. Critiques of the terms popular classes and popular culture have run the gamut from the logics of political economy to the droll (e.g., in a commentary on a lecture I gave in I993 at El Colegio de México, Daniel Cazés criticized me for calling Santo Domingo a colonia popular, because, he said, the truly popular colonias were those like Lomas de Chapultepec, where the wealthy classes resided, and everyone wanted to live in those communities). Several scholars have opted to downplay people's unequal relations to the means of production and have chosen instead to emphasize questions of inequality as reflected in the spheres of citizenship and consumerism (see García Canclini I995). ${ }^{11}$

In an insightful paper on political culture, Guillermo de la Peña posits that we should treat the concept of class as profoundly historical. We must cease to use the term class as a magic wand for categorizing groups of people so as to predict social behavior. Instead, de la Peña argues, if the term is to retain any of its salience, it must be utilized as a concept alive to the possibility of real people constructing real (and really) complex interpretations of their daily lives (I990, I05). It is no coincidence that this reevaluation of the constitution and consequence of classes is occurring at the same time that angst-ridden doubt and ironic uncertainty are on the rise, and that modernist (meta)truth and teleology are met with unchecked uncertainty and scorn. The key problem for those who would shuffle off to ironic oblivion may be that, like their overdetermining ancestors, they have too little insight and no plan to help resolve mundane matters like poverty, disease, and oppression in the world. Although there remains much to be altered and amended in class analysis, Michael Kearney is correct in writing that class analysis is still the "most powerful theoretical perspective for understanding the differentiation of identities in complex societies" (I996, 7-8).

AWKWARD AND INDECENT PROVOCATIONS

I conclude this preface by introducing three thorny questions that will reappear throughout the study to follow. 


\section{One: If everyone is a democrat, what is so great about democracy?}

Even if the meaning of democracy were clearer and more unanimously shared, the question remains: After all is said and done, why is this an age in which there is nary a self-professed anti-democracy advocate to be found in Mexico or any other corner of the globe? When women and men of all political stripes and persuasions tout democracy as the goal of humanity, the miracle of modern thought, and the salvation for the ills of this world, can democracy really be so good? When all alikefrom community anarchists to capitalist autocrats-peddle democracy as the solution to society's woes and wants, the time might be right to seek loftier ambitions. And, yes, to be clearer about what we mean by "democracy."

In his discussion of the lessons of the Euro-Communist movement for capitalism and democracy in Mexico, Roger Bartra remarks on what he calls "the extraordinarily 'subversive' potential of the struggle for democracy" (I98I, I48). The substance of such subversion is surely problematic when those in power are democracy's most visible and strident champions, and when they equate democracy with a singular economic regime, capitalism (see Amin I993).

I pose this query not merely as a quest for stricter definition, and certainly not merely as a call to choose among the various guises of the democratic creature, whether they be liberal, republican, bourgeois, or proletarian. Instead, I ask the question because today it seems valuable to ascertain whether a definition of democracy in today's world ought to encompass more than periodic trips to the electoral urns. If everyone is a democrat, and if everyone seeks to legitimate political thoughts and actions by reference to democratic instincts and approaches, then we are asking the wrong questions.

\section{Two: What is actually wrong with blaming the victim?}

The universal adoption of democracy as the goal of humanity has not resolved the issue of endemic poverty. And if all agree that agency is a wonderful thing to behold and defend, then the implications of agency for situations in which the powerless are less than brilliantly successful must be explored. If we regard agency as involving the successful incursion of the poor and powerless into the arenas of power, then we need to know more about agency's opposites. What on earth could they be 
called? "The system"? "Anti-agency"?! "Negagency"?!! If agency develops, in part, through an understanding on the part of los de abajo, the legendary social underdogs (see Azuela 1938), of their plight and how to lessen at least to some degree their misery, then the implications of agency when los de abajo misunderstand and misstep are best examined more frankly. We walk a fine line here between responsibility and reproach; yet the intricacies involved in distinguishing margins and avoiding pitfalls are certainly not reason enough to shun complicated social geography.

In contemporary Mexico, the expression "blaming the victim" is not commonly employed, and the debate about poverty is not framed in the same way as in the United States. Still, the fundamental questions are the same: Why does poverty persist? Who is responsible for poverty in the first place? Who is responsible for resolving this monstrous problem? "iViva México, hijos de la chingada!” (Long live Mexico, children of the damned!) millions of Mexicans shout on September I6th, Mexico's Independence Day. To be Mexican in this context, to be a Mexican who counts herself or himself as among the children of the damned, is to be socially damned and a sucker for accepting this state of affairs. ${ }^{12}$

If a majority of the populace in any country wants something, it does not automatically follow that their choices are democratically reasonable. When the rightist PAN candidate won the 2000 presidential election in Mexico, unseating the PRI, which had held the presidency continuously for seventy-one years, the change was quickly hailed as a sign of manifest democracy. But as Miguel Centeno presciently remarked three years earlier, "The possibility of a PAN victory in 1997 or in the year 2000 would provide exactly what technocrats wanted-democracy without the possibility of dramatic social change and with continuity in macroeconomic policy" (I997, 262). ${ }^{13}$ The truth of Centeno's prediction surely provides a counterpoint to the overheated declarations of democracy's lasting triumph that followed the 2000 presidential election in Mexico.

Leaving aside older considerations, of Benthamite majorities running amok and Durkheimian solidarities cohering harmoniously, the issue posed in various guises by my neighbors and acquaintances in Colonia Santo Domingo is simply this: whether, when, and how everyday folks will have a chance to significantly change anything substantial in the world. 


\section{Three: Is fascination with resistance a} postromantic substitute for socialism?

After 1989, any discussion of popular political cultures was inevitably influenced by what some have called "fall-of-the-Wall syndrome": after that date, the goals of socialism all but disappeared from activist, scholarly, and populist discourse even for those who all along had been less in thrall of politics in the former Soviet Union. So it was that the spirit of negative instance reigned among many former aficionados of socialism, and critiques of actually existing liberal democracies were refashioned with the understanding that there no longer existed a realistic hope for better societies.

In the I990s, the predominant framework by which to envision change in a postsocialist, postromantic age was through theories of resistance- of slow, covert, incremental struggles that, like barnacles, would accumulate, bit by bit, and eventually transform the world upon which they depended for sustenance. Nevertheless, in the real world of Mexico, and Latin America generally, social movements that flowered in the I970s and I980s provided analysts with more overt forms of struggle to study and debate. Often initiated around basic issues of survival - from water to land to housing — these movements provided real opportunities for the people most affected by these problems to organize, finance, and direct the political activities and goals of their own organizations.

Still, hidden resistance and in-your-face popular social movements were not easily transferable to the political sphere of political parties and formal political institutions. So it happened that popular politics became increasingly associated with local politics, with the micromanagement of general social problems. As a result of declining socialist fortunes - the near disappearance of Marxist dialogue from political debate - the political imagination of the Mexican populace became increasingly circumscribed and debilitated in the I990s and early 2000 s. In intellectual circles, resistance became the sensible substitute for the earlier quest for a radically better political world, a dream formerly known to many as socialism.

And so it was in Santo Domingo. In the I990s, there as elsewhere, political life often developed in other directions. 